
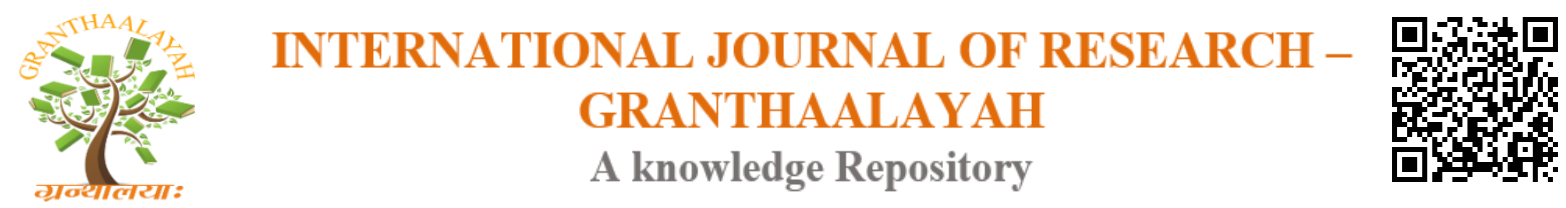

Management

\title{
ADMINISTERING THE FORUM ON CHINA AFRICA COOPERATION: EMPHASIS ON AGRICULTURAL RELATIONS
}

\author{
Zainab Gimba *1 \\ ${ }^{* 1}$ Department of Public Administration, University of Maiduguri, Nigeria
}

\begin{abstract}
The paper examines the administering of the forum on china-africa cooperation, looking at the cooperation in agricultural sector. The paper adopts the historical descriptive method of research to look into the development of the cooperation. Findings show that, chines contribution to agriculture goes beyond Africa, but covers many regions of the world and Africa benefits immensely in this cooperation. The paper concludes that china is doing its own best to see Africa grow agriculturally and expand to other areas of serving humanity. The paper recommends the involvement of all stake-holders in seeing that food security is assured in Africa.
\end{abstract}

Keywords: Administering; Forum; China-Africa; Cooperation; Agriculture; Relations.

Cite This Article: Zainab Gimba. (2018). "ADMINISTERING THE FORUM ON CHINA AFRICA COOPERATION: EMPHASIS ON AGRICULTURAL RELATIONS." International Journal of Research - Granthaalayah, 6(2), 312-323. https://doi.org/10.5281/zenodo.1194746.

\section{Introduction}

Chinese agriculture engagement in the African continent is growing rapidly and having an increasing impact on African development and agrarian change. This trend is often portrayed as a threat to the continent's development - part of a protracted effort to oust both Western and African control over land and politics on the continent. Chinese leaders, however, claim that their engagement is not only good for African agriculture, but also good for the entire world through support for Africa's potential to address global food security and further, that their unique approach to aid is leading to a 'modern revival of developing countries' worldwide, as traditional development actors are really out of touch with the realities on the ground. So we decided to do something radically different and very quickly, to be a catalyst for changes and reforms. This represents a radically different approach to engagement with Africa, an approach that can be called a paradigm revolution.

This chapter explores the contours of this revolution in the context of engagements in African agriculture, and asks what conversations are currently developing across various circles in Beijing on the subject. 


\section{Material and Method}

The paper adopts the secondary methodology of research, dealing with library materials such as books, journal articles, newspapers, magazines, reports and others. The paper is also supported by the theory of neo-functionalism propounded by Haas. The theory believes that, if states come together under intergovernmental cooperation to deal with a particular political, economic or social problems, it may have a spill-over effect to expand to other significant areas of interaction. This is relevant to the forum on China-Africa cooperation as the cooperation expands from economic to training, agriculture, infrastructure and many more.

\section{Findings and Discussion}

China's increasing engagement with African agriculture - through aid, trade and investments throughout the continent - is now a well-documented trend (Scoones et al, this IDSBulletin). The nature and significance of these engagements, however, continues to be hotly debated in media, academic and policy circles around the world. Three primary divergent narratives describing China's engagement in Africa can be summarised as follows: China as coloniser, economic competitor or development partner (Alden 2007: 5). The first two framings prevail in the media, emphasising China's engagement as a threat to Africa's development, especially in land and resource-related engagements such as agriculture. They present China's recent wave of aid and diplomatic efforts in Africa as part of a protracted effort to oust both Western and African control over land and politics on the continent. The second narrative sees China engaged in a self-interested, exploitative grab for resources to feed its fast-paced growth. Moyo (2012) admires China's 'commodity campaign', describing it as 'breathtaking,' stating that 'The Chinese are on a global shopping spree' in a zero-sum world of finite resources, and arguing that China's 'voracious commodity appetite is unlikely to abate' (Moyo 2012: 3).

Counter to these 'threat' framings, the development partner framing highlights the opportunities presented by China's engagement with African countries, emphasising the value of China's development experience for transforming Africa through South-South collaborative efforts. This development partner framing is seen in multilateral organisations, academic literature, as well as Chinese and African government discourse. In agriculture cooperation specifically, China is presented as a success story, ready to partner with African countries to support their success. For example, the United Nations Food and Agriculture Organization (FAO) argues that 'Chinese science and agriculture have much to offer to other developing countries, since intensive smallscale agriculture has been practised in China for centuries,' and points out that 'China repeatedly demonstrated its commitment to helping other developing countries to improve their food security' (FAO 2012). Discussing China's engagement in African agriculture, the literature has attempted to debunk myths about so-called large-scale Chinese farming for export. It has repeatedly argued that the scale of China's engagement is still unclear but likely much smaller than claimed (Smaller et al. 2012; Brautigam and Tang 2012; Scissors 2010), and that most production is currently not exported (Buckley 2012; Brautigam 2009).

China's engagement in African agriculture development thus remains highly contested. Despite an increasing body of more thoughtful, evidence-based research looking into the nature of these engagements, there is a persistent lack of analysis of Chinese perspectives. Whether seen as a 
threat or opportunity, 'China' is generally portrayed as a monolith, guided by a strong policy directive and ruled by a central coordinating force in Beijing. For example, Deborah Brautigam writes that China's 'embrace of the continent is strategic, planned, long-term and still unfolding' (2012: 7).

The debate on the implications of this Sino-African cooperation in agriculture however will not be resolved without a deeper understanding of the diversity of Chinese agriculture engagements in specific African contexts, and the nature of Chinese narratives on the subject.

\subsection{China-Africa Agricultural Cooperation}

China has been involved in African agriculture for more than 40 years. Early engagement was largely motivated by a need for the new Chinese nation to build soft power and recognition on the global stage. Activities were characterised by bilateral agreements and donation-based aid. In return for their friendship and assistance, countries had to adhere to the 'One China' policy, which required countries to recognise Taiwan as part of the People's Republic of China. These efforts played an important role in China's successful bid for a UN seat and remain important allies in international negotiations (Renard 2011: 7, 12). The One China policy is still in effect today.

During China's Reform Period in the 1980s and 90s, engagements in Africa took a 'consolidation' approach focusing on science and techniques implemented by joint venture-supported grants (Brautigam and Tang 2012b). In recent years, following China's joining of the World Trade Organization (WTO) and the launch of its official 'Go Out' policy in the early 2000s, China's focus has shifted to support for Africa's economic liberalisation and integration into the global agriculture commodity market. This has meant support for development of export-oriented production, experimentation with Special Economic Zones (Renard 2011; Berthelemy 2011), exemptions from customs duties, large infrastructure projects, and Chinese ODI in Africa (Renard 2011: 20). These engagements still include bilateral and aid-based approaches, but are increasingly characterised by multilateral and regional engagements, and by mixed aid-tradeinvestment packages.

\subsection{Historical Context and Current Drivers}

In early forays into the international scene, Chinese officials - led by Mao and his anti-imperialist agenda - were quick to assert that China was distinct from colonial powers and that it came in friendship and solidarity. Today this has evolved into China's assertion of itself as 'the largest developing country in the world' (GOV, 2010: 2) which is providing assistance to African countries 'despite its own economic hardship' (GOV, 2010: 5). Emphasising their shared challenge of development, Chinese leaders thus assert a moral imperative to share their experience as they show 'great concern for the livelihood for African people' (GOV, 2010: 7).

Indeed, China's own modernisation project grew out of a sense of indignation at its perceived mistreatment by the West. The result has been a deep belief among leaders that China needed to forge its own path towards modernisation, a path independent and distinct from that of the West. China's insistence on not interfering in domestic political affairs of other countries stems from this experience. As then Chinese president Hu Jintao stated in the recent Forum on China Africa 
Cooperation (FOCAC) ministerial in Beijing, 'China wholeheartedly and sincerely supports African countries choosing their own development path, and will wholeheartedly and sincerely support them to raise their development ability' (CCTV, 2012).

China's approach to Africa has been to experiment with the approach China has taken to modernise and liberalise its own rural economy. Agriculture played a central role in China's own economic development and sharing these experiences has been a consistent priority in China's engagements in Africa ( $\mathrm{Li}$ et al., this IDS Bulletin). Agriculture cooperation has focused on technocratic and capacity- building interventions, and deliberately shied away from social and political issues. Since launching its 'Go Out' policy and joining the WTO in 2001, China has promoted itself as an active member of the global community, encouraging agricultural trade and overseas direct investments. Chinese leaders still see the global community as unfairly dominated by a small handful of countries at the expense of the vast majority. They consistently reject OECD aid models, interpreting the use of conditionalities as 'merely the latest in the decades of humiliating experiences at the hands of former colonial powers and the United States' (Alden 2007: 20).

The message is clear, Chinese agriculture did not get where it is today through DAC-guided aid. It got there through a mix of market reforms, trade and foreign direct investment (FDI), and that is precisely what it is doing in Africa. The result is a focus on providing 'multi-level and multi form cooperation' to contribute to improving agriculture production, strengthening Africa's food security, technical exchanges, human resources training, agriculture development plans, and agriculture processing and machinery (FOCAC 2012). This includes a commitment to 'encourage Chinese financial institutions to support corporate cooperation' in agriculture development. Chinese engagement in global agriculture is also guided by changing consumption patterns in China and increasing resource pressures on an over taxed domestic agriculture sector. Though China has been highly successful at feeding more than 20 per cent of the world's people with only nine per cent of its arable land, its leaders are 'not optimistic about its food security situation' as the country 'faces shrinking arable land resources, water shortages, frequent disasters, deteriorating arable land quality and other agricultural production challenges including climate change' (Liet al. 2012: 245).

Agriculture engagement in Africa today is framed as 'South-South' collaboration, emphasising reciprocal relationships with 'mutual benefits'. It continues to enhance political relationships and soft power, while also boosting commercial opportunities for national firms and increasingly, also serves to strengthen Chinese resource security (Brautigam and Tang 2012b; Brautigam 2012; Liet al. 2012; Qi 2012; Renard 2011). It also continues to be informed by China's own domestic development experience and shaped by policy changes within African countries and by global economic trends ( $\mathrm{Li}$ et al. 2012). 
Table 1: Formal agenda of China-Africa agriculture cooperation

\begin{tabular}{|l|l|}
\hline \multicolumn{2}{|c|}{ Beijing Action Plan (2012-2015) } \\
\hline Sections & Pledged actions by China: \\
\hline 4.1 .3 & Support CAADP (Comprehensive Africa Agriculture \\
\hline & Development Programme) for a 'growth-oriented' \\
\hline & agricultural agenda for Africa \\
\hline 4.1 .4 & Send teams to train African agricultural technicians \\
\hline 4.1 .4 & Support agricultural vocational education system and send \\
\hline & Teachers \\
\hline $4.1 .4 \& 5.2 .1$ & Build more agriculture demonstration centres \\
\hline 4.1 .4 & Provide technical support for grain planting, storage, \\
\hline & processing and circulation \\
\hline $4.1 .4 \& 4.5 .6$ & Encourage Chinese financial institutions to support \\
\hline & corporate cooperation in planting, processing, animal \\
\hline 4.1 .4 & husbandry, fisheries and aquaculture \\
\hline $4.1 .4 \& 4.1 .6$ & Support UNFAO 'Special Program for Food Security' \\
\hline & Facilitate access for African agricultural products to the \\
\hline 4.5 .2 & Chinese market \\
\hline & US\$20 billion credit line for infrastructure, agriculture, \\
\hline 6.3 .6 & manufacturing and African SMEs \\
\hline & Publish and translate agricultural technology materials; \\
\hline & joint participation in book fairs in China and Africa \\
\hline
\end{tabular}

\section{Source FOCAC 2012}

To the Chinese leadership, economic and trade cooperation is a prerequisite for promoting economic development and social progress (GOV 2010: 2). Chinese ministries, banks and companies are thus all involved in agricultural cooperation with African countries. Though there are at least 23 ministries and agencies involved in these engagements (Kragelund 2008).

The Ministry of Commerce (MOFCOM) plays a central role through its Department of Foreign Aid and Department of Outward Investment and Economic Cooperation. MOFCOM coordinates with the Ministry of Agriculture (MOA) and Ministry of Science and Technology (MOST) for agricultural programs, which are then implemented by Chinese institutes, state owned enterprises (SOEs) and private firms through a competitive bidding processes. Financing for the implementation is partially sourced from the China Development Bank (CDB) and the Export Import Bank of China (China EXIM) in the form of commercial development finance and export credit. The China-Africa Development Fund (CADFund) was established in 2006 to promote the development of Sino-African commercial ties. It has a strategic agreement with the China State Farm Agribusiness Corporation to establish a joint company to make agriculture investments.

The Forum on China Africa Cooperation (FOCAC) was established in 2000 to provide an interface with African partners and relevant Chinese actors. FOCAC ministerial meetings are held every three years alternating between Beijing and African countries and continue to provide an important policy framework and platform for engagement. Increasingly, Chinese NGOs and 
researchers are developing interest in these engagements as well, and are beginning to explore ways to influence key actors and policies governing them.

It can be difficult to obtain reliable data on the scale and depth of China-Africa agricultural cooperation. This is further complicated by the fact that assistance to Africa is administered by at least two dozen agencies and ministries (Kragelund 2008). Where aid projects are explicitly discussed in Chinese government and media reports, the tendency is to emphasis impacts on the ground, for example, citing numbers of infrastructure projects built, trainings held, or people treated for a disease. As a whole, this aid is growing fast, however, it is still relatively small compared to aid from OECD countries (Grimmet al.2011). Davies estimated total aid to Africa between 1949 and 2006 to be valued at US\$5.6 billion (Davies 2006). Aid flows on a yearly basis have also produced a wide range of estimates such as: US\$1-1.5 billion in 2005 (Wang 2007); or US\$850 million in 2007 (Brautigam 2012; Axel et al.2011; Kragelund 2008).

According to the State Council, by the end of 2009 China had 142 agriculture projects in Africa and had provided a large amount of agriculture equipment and materials (GOV 2010: 7). Agriculture aid comes in both monetary and in-kind forms to support food production, breeding, storage and transport, infrastructure development as well as in the form of agriculture equipment, trainings, technical assistance and scholarships (GOV 2010: 7). Chinese banks play a key role as well, offering financing services in agriculture and financing agriculture development projects (Brautigam 2012; Berthelemy 2011: 11). Although aid is not tied to governance or policy requirements in recipient countries, China only provides aid to countries that recognise the One China policy - currently, there are 49 such countries in Africa (Brautigam 2012). Commercial interests can also be seen in China's monetary aid which is tied to the use of Chinese goods and services. Indeed, Chinese aid has often been criticised as being tied to commodities, with large lines of export buyers, credit sometimes secured with commodities, especially in resource-rich countries such as Angola, the Democratic Republic of the Congo and Equatorial Guinea. These act as a kind of complicated long-term trade arrangement, with financing up front (Brautigam 2011).

Trade has been rising in significance since 1974 following Chinese liberalisation (Renard 2011). Total trade between China and Africa has grown rapidly, from US\$12.14 million in 1950 to US $\$ 1$ billion in 1980, then US\$10 billion in 2000 to a reported US\$100 billion in 2008 (GOV 2010: 3). Recent Ministry of Commerce figures put trade at US\$166.3 billion in 2011 (Mu 2012; PDO 2011). China emphasises its role as a 'stable market' for African exports, especially of local specialities (GOV 2010: 3), and provides zero tariff imports of a wide range of agriculture goods from 45 Least Developed Country partners since 2005. Investment is also increasing rapidly, covering 49 African countries in a wide range of sectors by a diversity of actors including SOEs, private enterprises and individuals (GOV 2010: 4). In 2011, Chinese investments in Africa were calculated at US\$14.7 billion from over 2000 enterprises (Mu 2012), and agriculture has been identified as a 'core' focus for future investments (Ncube 2012).

Chinese agriculture investment figures have also been a source of much confusion, with much large scale, food crop investment proposals being cited as operational Chinese land grabs or export back to China. Increasing evidence however, suggests that China is not engaged in largescale African farming for export (Brautigam and Tang 2012; Scissors 2010; Large 2008). 
Smaller et al. (2012) were only able to confirm the existence of 54 Chinese overseas projects covering 4.9 million hectares of land. Of those 54 projects worldwide, only 32 (covering 1.4 million ha) are operational and only 463,792ha (nine per cent) are in Africa.

Overall, focussing on the aggregate size of Chinese aid, trade and investment masks the diversity of Chinese agricultural engagements and fosters misunderstanding. It also tells us little about why these engagements are happening, and what the impacts are.

\subsection{Discourses on China-Africa Cooperation}

To build such an understanding of the patterns and motivations underlying Chinese agriculture cooperation with Africa, it is useful to analyse how different Chinese actors talk about these engagements, how they envision African agriculture, and how they understand China's place in global agriculture and food security. Discussions with around 30 informants about China-Africa cooperation were undertaken, including Chinese nationals posted in Africa, officials involved in policy-making alongside civil society, media and diplomatic representatives.

\subsection{Framing China-Africa Cooperation}

In the Beijing Action Plan drawn up in the 2012 FOCAC ministerial in Beijing, Chinese leaders set out their vision and plan for China-Africa cooperation over the next five years (FOCAC 2012). Table 2 lists the frequency of selected words used in this document.

Table 2: Frequency of select phrases used in FOCAC Action Plan 2012

Source: FOCAC, 2015

\begin{tabular}{|l|l|}
\hline Phrase & Occurrences* \\
\hline cooperation & 140 \\
\hline two sides & 132 \\
\hline developing/-ment & 75 \\
\hline exchange & 68 \\
\hline mutual/joint/together & 49 \\
\hline strengthen/benefit & 41 \\
\hline agriculture & 28 \\
\hline food security & 11 \\
\hline
\end{tabular}

This sense of solidarity and shared development opportunities with Africa was emphasised in many interviews. As a consultant in a Chinese overseas investment consulting firm explained, 'Chinese companies do well in Africa because we come from a developing country and we have ways of dealing with certain issues [that also apply in Africa]. They are in a poverty trap. China faced exactly the same problem 100 years ago.' A Chinese agronomist who had worked in a Sino-Senegalese agriculture training programme reasoned, 'Our experts and technicians are all hard-working and can endure hardship. They've been through difficult times in China's recent past, so Africa is not such a difficult adjustment for them. 
The sense that China has unique development experience to offer is also echoed in discourse of non-Chinese actors. For example, Zambian writer Dambisa Moyo (2010) asserts that the OECD aid model has failed African countries and suggests that China's approach offers a meaningful path forward. A China Exim economist explains, 'The urgent need for Africans is to feed their bellies, so social justice needs to be above political democracy'. The White Paper on ChinaAfrica Economic and Trade Cooperation issued by FOCAC in 2010, China's leadership asserts that China's approach to Africa 'in fuses new life' into South-South cooperation while 'promoting the establishment of a fair and rational new international political and economic order' (GOV 2010: 2).

\subsection{Technological and Market Optimism}

China's approach to Africa has been to experiment with the approach China has taken to modernize and liberalise its own rural economy. Chinese agriculture cooperation tends to be heavily technocratic because this has been China's experience too - to focus on technology and market development, and allow different Chinese regions to adapt specific uses to their own needs.Many informants emphasised the importance of technology. In addition to the 'hard' technologies of irrigation, Chinese crop varieties, and farm equipment, agriculture cooperation also focuses on the 'soft' technologies of capacity building and skills transfer. Other informants pointed to market barriers in Africa which they perceived to be preventing agriculture development. A leading economist at China Exim, for example, explained that agriculture cooperation with Africa should not just be about transferring Chinese techniques - it also needed to focus on the market. The Chinese leadership and investors also have an interest in stabilising markets in Africa because, as one Chinese investment consultant notes, 'Market volatility represents a major risk for Chinese investment in African agriculture' (Li et al.2012).

\subsection{Solving Global Food Security}

Although Chinese leaders believe deeply in their approach to agricultural modernisation and in the effectiveness of their technologies and global markets to support them, they are less optimistic about the future potential of additional domestic agriculture growth. Chinese policymakers think better food self-sufficiency in Africa will reduce others' dependence on international agricultural markets, and thereby also ease China's own situation (Li et al.2012). The FOCAC White Paper explains, 'China always regards helping Africa solve its food security problem as its ultimate goal in China- Africa agriculture cooperation' (GOV 2010: 7). The Chinese agronomist in Senegal explained, China has relatively little arable land compared to other countries but an enormous population, and yet we have been able to rely on our own abilities to feed ourselves. We can use this experience to help solve [Africa's] food supply problems. The argument that Chinese technologies and experience might be used to address global food security is increasingly echoed in the international development community as well (Boet al.2013; Brautigam and Tang 2011).

Informants rejected the notion that China-Africa agriculture cooperation is purely for China's self- interest, asserting that though China does have a food security problem, the focus is on addressing global food security as a global, holistic issue, not for growing food in Africa for direct export to China. The agriculture policy advisor at the Chinese Academy of Sciences 
(CAS) similarly explained: Media coverage of these issues is very biased. China is helping Africa improve global food security. China does want to increase food exports from Africa, but not necessarily directly to China.

\subsection{Alternative narratives}

While mainstream Chinese discourse on China-Africa agriculture cooperation focuses on the mutual advantages of each side and the opportunities these create, some actors are developing more critical perspectives and offering alternative frameworks for thinking about China-Africa agriculture cooperation.

\subsection{Technology Transfer in a Vacuum}

Not everyone agrees that Chinese technology is appropriate for Africa, or indeed that China's development experience can be adapted to Africa's benefit. Informants criticised the assumptions of shared experience between China and Africa. As a project officer of a Chinese grassroots NGO worried, 'Aid is supposed to help local people develop by introducing China's experience. But people forget to ask whether this is appropriate or not. Chinese people don't understand African history or the development situation.' The agriculture policy advisor at CAS similarly suggests that Chinese agriculture technology transfer has not been very effective because Chinese workers don't understand Africa. In short, he says, 'Africa doesn't understand China, and China doesn't understand Africa.' This lack of understanding is further compounded by the Chinese tendency to segregate themselves from local populations when implementing a project, leading to misunderstandings and racism. Misunderstandings have developed on both sides.

\subsection{Cooperation towards what kind of agriculture?}

Also of concern was that China's own agriculture development was creating problems, and that lessons from these issues were not being carried forward into cooperation with Africa. A Chínese NGO project officer argued that in Africa, the average land to person ratio is quite high, so there's no real need to use China's model of high investment, high polluting agriculture. Similarly, the CAS economist argued that handing out technologies won't have any take up. We've seen this with the experience of bio gas in China. The agriculture policy advisor at CAS was equally critical of the emphasis on technology transfer above other factors, the Gates Foundation is spending $\$ 1$ billion on agriculture technology for Africa. But not all technology is necessarily useful for Africa.

In China, rural development started with land tenure reform, not with technology. There is also concern that Chinese actors may be having unintended social impacts through their focus on the government leaders and elites. A Chinese NGO worker commented: Even where China may have valuable models to share, she said, it is unclear whether the necessary training reaches the right people. Informants also recognise the problem of Chinese segregation, suggesting that Chinese enterprises top-down management system makes them focus greater attention to maintaining good and strong relations with local government representatives such that they do not develop sufficient connections with other local powerful organizations, such as the labour unions, other stakeholder groups, or NGOs, they pay. 
Informants in international NGOs in China stressed the need to improve the governance of social and environmental impacts of China-Africa cooperation. Coverage of the FOCAC meetings has not generally included the environmental sector. The ideal would be that Chinese investments would create minimum environmental impacts and provide direct benefits to local communities. We also hope to achieve formal NGO participation in future FOCAC meetings commented an international NGO representative. A Chinese NGO officer commented: Our focus is on how to protect the farmers interests. I believe that we need to support grassroots organizations in Africa and in China to be able to find sustainable solutions. There's a need for greater disclosure of information in order to help Chinese groups be more aware of these issues and collaborate to find solutions.

\section{Conclusion}

China's leadership asserts that China's approach to Africa 'infuses new life' into South-South cooperation, elevates the political and economic status of developing countries in the world and contributes significantly to promoting the establishment of a fair a rational new international political and economic order (GOV 2010: 2). Chinese agriculture engagements are redefining the aid landscape, moving from a paradigm of development assistance to one of development cooperation mixed with investment. However, the specific nature and impacts of these engagements are still emerging.

The paper has attempted to contribute to this exploration through a presentation of the discourse, justifications, and critiques underpinning this cooperation. A more advanced understanding of Chinese motivations overseas can build a more realistic understanding of the strengths and weaknesses of China's own agriculture models. For example, Chinese researchers and policymakers acknowledge that using agribusiness investments as development aid comes with risks and uncertainties. Even though an enterprise approach can make agriculture projects more financially secure, integrating the non-profit and profit making functions remains a challenge. There is room for dialogue around this approach, and need for tools enabling Chinese companies to share benefits with local communities.

As China's agriculture engagements grow throughout the continent, Chinese discourse has contributed to a reframing of African agriculture from degraded and hopeless, to a landscape of opportunity and promise. Characterised by a Malthusian world view of resource scarcity and a crisis scenario about global food security, Chinese narratives of African agriculture are articulated around a critical assumption: Entitlement to environmental assets is directly proportional to the capacity to produce with them - and further that Chinese are the most efficient users of agricultural resources. With involvement of the Chinese in African agriculture, the crisis scenario is thus replaced with a new vision of harmony, with China and Africa working together in a win-win project of ecological modernisation.

This framing is further aided by increasing disillusionment with the prevailing aid paradigm in Africa, giving the opportunity for Chinese actors to claim stewardship over agricultural resources on the continent. Presented as a politically neutral concern for the common development needs shared by China and African countries, the narratives are able to largely fence out inconvenient questions, for example, about problems with agriculture practices within China, or unclear land 
tenure within African countries. The assumption is that technical interventions are needed to turn Africa's 'undervalued' environmental potential into social and economic benefit.

Despite some debate and criticism about Chinese agriculture cooperation in Africa, this framing works as a powerful narrative because it arrives at a convenient point of convergence for the interests of the central constituents in these engagements: 1) Chinese leaders who stand to gain from increased soft power in Africa; 2) African leaders who will benefit both from increased agriculture production and trade in their countries and from positive relations with China as a rising power; and 3) Global actors concerned about Africa's underdeveloped agriculture, which is understood to require input from more efficient resource-users. Those who are outsiders, such as risk-averse Chinese investors, are being brought into the circle through financial incentives and removal of trade barriers. Researchers and civil society, however, remain on the outside and are thus free to ask critical questions of the dominant narratives and underlying assumptions.

Despite the small number of informants, what emerges from this exploration is a widely varied set of interpretations of Chinese discourse on China-Africa agriculture cooperation. We see that cooperation is a dynamic process informed and shaped by China's socio-cultural and development history, the ongoing experiences of individual actors in Africa, and personal ambitions and dreams for the future. We see creative thinking about how to solve problems and improve on the engagements.

Perhaps then the paradigm shift in African agriculture comes not from what China is doing - or not doing - differently on the ground, but rather, from a shift in how the world perceives Africa's agrarian future and China's role in it. However, it is still unclear how much China's discourse of opportunity will hold true for African partners. The assumption that Africa's agriculture is undervalued and underdeveloped begs the question, underdeveloped by whom? If Africa's agriculture potential is to be developed, how is this potential defined and for whose benefit? More research is needed problematising China's own agriculture development model and its assumed success. While China has made impressive progress towards increasing its total food production, this has been achieved at the cost of heavy depletion of its water and soil resources, intense fertiliser use with associated high pollution and energy use, and social exclusion of large fractions of society. It remains unclear whether the agriculture development models being transferred in China's South-South exchanges will replicate these problems in Africa.

Furthermore, if the Chinese model for agriculture cooperation in Africa is to provide technocratic inputs, there is a need to explore more deeply to what degree cooperative partners are able to adapt those tools to meet their needs. Despite rhetoric of mutual benefit on both sides, thus far, China has generally taken the lead in agriculture project design and implementation with only passive participation from African partners. This has led to frustrations on both sides project failures, and unexpected consequences on the ground (Buckley 2011). There is particular excitement among researchers and some practitioners around the potential for emerging trilateral relationships to address some of these problems, overcome structural barriers and increase transparency. However, very little empirical evidence exists to substantiate the claimed potential benefits of these arrangements. Further exploration of how the multiplicity of Chinese agriculture cooperation modalities function on the ground in specific context is needed. 
Chinese assumptions about achievable food self-sufficiency in developing countries shape China's policy framework for global agriculture aid, trade and investments. Understanding the underlying motivations can spur local countries to develop their own vision for global food security and their place in it, and to determine how best to engage Chinese actors to achieve these goals. Whether or not global Chinese agriculture activities alleviate food security challenges, they are certain to alter production and consumption patterns of local farming communities around the world. Without constructive and active engagement, 'mutual-benefits' will likely remain confined to the Chinese and local elites - at the expense of the local environment and farming communities. Development actors (both local and global), researchers and NGOs all have a role to play in developing visions and policies for global food security and sustainable agrarian futures, and placing China's increasing global engagement within this framework.

\section{References}

[1] Alden, C. (2007) China in Africa, London: Zed Books

[2] Axel, B., Brautigam, D. and Baumgartner, P. (2011) 'Why Are We So Criticai about China's

[3] Engagement in Africa?'Current Column, German Development Institute, translated as 'Die Kritik an Chinas Entwicklungshilfe ist übertrieben', Die Zeit (Germany), August 16

[4] Berthelemy, J.C. (2011) China's Engagement and Aid Effectiveness in Africa,African Development Bank Group Working Paper Series 129,

[5] Bo, R.; Hongqiao, L. and Fang, L. (2013) 'For Gates Foundation, Philanthropy is a Two-Way Street', Caixin Online, http://english.caixin.com/2013-02-27/100495070.html (accessed 2 April 2013)

[6] Brautigam, D. (2012) 'Dispelling the Myths of China's Presence in Africa',This Is Africa, www.thisisafricaonline.com/Business/Dispelling-the-myths-of-China-s-presence-in-

Africa?ct=true(accessed 2 April 2013)

[7] Brautigam, D. (2011) 'Aid "With Chinese Characteristics": Chinese Foreign Aid and Development

Finance Meet the OECD-DAC Aid Regime', Journal of International Development 23.5: 752-764

[8] Brautigam, D. (2009) The Dragon's Gift: The Real Story of China in Africa,Oxford; Oxford University Press

[9] Brautigam, D. and Tang, X. (2012a) An Overview of Chinese Agricultural and Rural Engagement

Ethiopia, IFPRI Discussion Paper 01185, Development Strategy and Governance Division, Washington, DC: International Food Policy Research Institute

[10] www.ifpri.org/sites/default/files/publications/ifpridp01185.pdf(accessed 2 April 2013)

[11] Brautigam, D. and Tang, X. (2012b) Economic Statecraft in China's New Overseas Special Economic

Zones: Soft Power, Business, or Resource Security? International Food Policy Research Institute (CGIAR) Discussion Paper 01168

www.ifpri.org/sites/default/files/publications/ifpridp01168.pdf(accessed 2 April 2013)

[12] Brautigam, D. and Tang, X. (2011) 'China's Investment in African Special Economic Zones: Overview and Initial Lessons', in T. Farole and G. Akinci (eds), Special Economic Zones: Progress, Emerging Challenges, and Future Directions, Washington, DC: The World Bank

*Corresponding author.

E-mail address: sherfboy@ yahoo.com 